\title{
The Effect of Viral Hepatitis ON APTT, PT, TT, Fibrinogen and Platelet among Blood Donors at FMC, Umuahia
}

\author{
Okoroiwu Ijeoma Leticia ${ }^{1}$, Anode Andrew ${ }^{2}$, Obeagu Emmanuel Ifeanyi ${ }^{3}$, \\ Udokwu Euphemia Ifeoma ${ }^{2}$ and Amadi Ugochukwu ${ }^{4}$. \\ ${ }^{1}$ Lecturer(P.hD),Department of Medical Laboratory Science, Faculty of Health Science, Imo State University, \\ Owerri, Nigeria. \\ ${ }^{2}$ Department of Medical Laboratory Science, Federal Medical Centre, Umuahia, Abia State, Nigeria. \\ ${ }^{3}$ Diagnostic Laboratory, UniversityUnit, Health services Department, Michael okpara University of \\ Agriculture,Umudike,Nigeria.emmanuelobeagu@yahoo.com \\ ${ }^{4}$ Department of Medical Laboratory Science, Federal Medical Centre, Owerri, Imo State, Nigeria.
}

\begin{abstract}
The effect of viral hepatitis on some coagulation parameters APTT, PT,TT,Fibrinogen and platelets were determined among blood donors at FMC Umuahia. One hundred and sixty three blood donors were sampled comprising One hundred and thirteen as follows; (HAV 16, HBV 65 and HCV 32) and fifty non hepatitis subjects who served as control. The parameters were analysed using standard haematology technique. Results obtained showed no statistical significant changes in the coagulation parameters in HAV subjects (32.8 \pm 2.6$)$ secs, $12.4 \pm 1.5$ (secs), $16.7 \pm 1.3$ secs, $2.9 \pm 0.2 \mathrm{~g} / \mathrm{L}$ and $249 \pm 7310^{9} / \mathrm{L}$ when compared with control group 34.1 \pm 3.1 secs $13.4 \pm 1.7$ secs $16.7 \pm 1.5 \operatorname{secs} 2.5 \pm 0.6 \mathrm{~g} / \mathrm{L}$ and $(263 \pm 74) 10^{9} / \mathrm{L}$ respectively for the parameters as stated above $(P>0.05)$, significant change in HBV infection $42.4 \pm 5.8$ (secs); $22.3 \pm 10.7$ (secs); $23.9 \pm 4.7$ (secs); $1.8 \pm 1.1(\mathrm{~g} / \mathrm{L}) ;$ and $162 \pm 144\left(10^{9} / \mathrm{L}\right)$ when compared with the control $34.1 \pm 3.1$ (secs); $13.4 \pm 171$ (secs); $16.7 \pm 1.5$ (secs); $2.5 \pm 0.6 \mathrm{~g} / \mathrm{L}) ; 26 . \pm 74\left(10^{9} / \mathrm{L}\right)$ respectively at $P<0.05$. The HCV infection showed the same significant changes in all the coagulation factors estimated; $45.0 \pm 6.3$ (secs); $20.9 \pm 4.9$ (secs); $24.6 \pm 5.6$ (secs); $1.6 \pm 0.6(\mathrm{~g} / \mathrm{L})$ and $170 \pm 61\left(10^{9} \mathrm{~g} / \mathrm{L}\right)$ when compared with the same control group. The APTT showed a positive relationship with $P T$ and TT and a negative relationship with fibrinogen and platelets. PT had a strong positive correlation with TT and a negative relationship with fibrinogen and platelet. TT showed a strong negative relationship with fibrinogen and platelet. The result showed an alteration in the levels of coagulation factors following viral infection of the liver.
\end{abstract}

Keywords: APTT, PT, TT, Fibrinogen and Platelet.

\section{Introduction}

Viral hepatitis is the inflammation of the liver due to viral infection. It is a major public health problem worldwide and the principal cause of cirrhosis and hepatocarcinoma (Franscesca et al., 2009). The most common causes of viral hepatitis are the five unrelated hepatotropic viruses among others; hepatitis A, B and C, infecting more than 2 billion people globally (Emechebe et al., 2009).

It may present in acute or chronic forms as it is characterized by the presence of inflammatory cells in the tissue of the organ, it can be self-limiting or progress to fibrosis and cirrhosis (Rhyder et al., 2001). The liver which is the largest organ in the human body with hepatocytes as its functional unit separated by wide vascular channels known as the sinusoids (Young and Health, 2000), is faced with many functions including the production or synthesis of most of the clothing and fibrinolytic proteins and the clearance of these coagulation factors from the circulation.

The central event in the coagulation is the production of thrombin which acts upon fibrinogen to produce fibrin and thus the fibrin. And the clot is further strengthened by the crosslinking action of factor XIII which itself, is activated by thrombin (Dacie and Lewis, 2001), which is geared toward arresting bleeding. Hepatitis A Virus (HAV) is been transmitted by the fecal-oral route often associated with infection of contaminated food. It causes an acute form of hepatitis and does not have a chronic stage. Hepatitis B virus can cause both acute and chronic hepatitis like hepatitis C virus. They can be transmitted through blood, tattoos; sexually and mother to child.

The progressive loss of hepatic parenchymal cells as a result of increased aptosis caused by Oxidative stress secondary to increased production of reactive molecules, leads to hepatic dysfunction and among all these complications, haemostatic alterations have been considered for a long time, the principal cause of bleeding in cirrhotic patients (Francesca et al., 2009).

The deficiency of vitamin $\mathrm{K}$ as a co factor also inhibits the post translational gamma-Carboxylation of glutamic acid residues of Vitamin K dependent factors (Blanchard et al., 1981), hence, a defect in haemostasis. 
Studies have reported prolongation of PT, aPTT, TT following viral hepatitis with dysfibrinogenemia and thrombocytopenia (Hyer et al., 2011). This is because of the loss of the integrity of both the extrinsic pathway of coagulation and the factors of the common pathway. And the degree of prolongation of this clothing time has been suggested to correlate to the degree of deficiency or inhibition of extrinsic or common pathway clothing factors, hence the severity of the liver disease (Hyer et al., 2001).

The loss of hepatic function following HBV infection could arise from hepatic inflammation caused by HBX (hepatitis B Virus X protein) which is a major viral transactivator and induces many pro-inflammatory cytokines including interleukine-18 (1L-18). The IL-18 in turn increases the expression of Fasl (Fas-Ligard) which leads to increased susceptibility to fas-medicataed cell apoptosis.

$\mathrm{HCV}$ infection is characterized by increased oxidative stress resulting in a chronic inflammation as a result of increased production of inflammatory cytokine. The reactive oxygen species (ROS) generated in the course of HEV infection tend to nonspecifically oxidize essential biological macromolecules, consequently, leading to acute cell damage or gradual deterioration of important cell functions. This oxidative stress has been shown to induce the proliferation of hepatic stellate cells, T G F - $\beta$ collagen synthesis (Poli, 2000) which play an important role in the development of liver fibrosis.

The increased levels of ROS in Viral hepatitis have been suggested to promote the development of hepatocellular carcinoma by inducing DNA damage and mutation of cellular genes. Some HCV proteins have been implicated in the oxidative stress as NS5A has been suggested to increase mitochondrial ROS generation by Perturbing the cytosolic $\mathrm{Ca}^{2+}$ (Calcium) concentration indirectly through endoplasmic reticulum (ER) stress. The NS3 protein of HCV induces oxidative stress by activating Nicotinamide adenine dinucleotide phosphate oxidase (Nox 2) of Kupffer cells and ploymorphonuclear cells in the liver and to trigger apoptosis. (Thoren et al., 2004).

It is this progressive loss of hepatic parenchymal cells, occasioned by these virus that result in clothing factor deficiencies and elevations as the case may be. There was marked thrombocytopenia in HBV and HCV infections as observed in this work. This could be explained from the impaired hepatic synthesis of protein which is the principal physiologic regulator of platelet production and synthesized constitutively in the liver (Kuter and Begley, 2002).

The thrombocytopenia could also arise from increased sequestration of platelet in an enlarged spleen as well as the production of nitric oxide which is a powerful vasodilator and inhibitor of platelet adhesion and aggregation. This is in agreement with the finding of Young Xiang et al., (2002), that platelet count correlates inversely with the number of phagocytically active splenic macrophages, supporting their role in the pathogenesis of thrombocytopenia.

The changes observed in the coagulation factors can be attributed to the progressive loss of hepatic parenchymal cells from apoptesis hence, loss of functional integrity. It could also arise from vitamin $\mathrm{k}$ deficiency which is a required co factor for gamma-carboxylation of glutamic acid residues on vitamin Kdependent factors. As this is a modification required for binding to phosphoslipid surface (Blanchard et al., 1981).

\section{Justification Of Research}

The incidence of death secondary to Hepatitis in Nigeria is becoming alarming. No much work has been done within our locality to determine the complications associated with this mortality rate. It is therefore, justifiable to determine the effect of Hepatitis (A, B \& C) on these coagulation factors on these. This research will contribute to medical knowledge and the management of patients with Hepatitis, giving cognizance to associated coagulopathies.

\section{Aim}

To determine the effect of Hepatitis A, B and C on some coagulation factors (APTT, PT, TT, fibrinogen and platelets).

\section{Objectives}

1. Determine the levels of platelets count on Hepatitis A, B and C positive subjects.

2. Determine the fibrinogen and APTT level on Hepatitis A, B and C positive subjects.

3. Determine the prothrombin time on Hepatitis A, B and C positive subjects.

\section{Materials And Methods}

\section{Study Area}

The study was conducted at the Blood group and serology unit of Federal Medical Centre Umuahia. Umuahia is the capital of Abia State, with a population of 264,662 and covers a land area of about $245 \mathrm{~km}^{2}$. It lies on latitude 
5.52627(decimal degree)north and longitude 7.48959(decimal degree) East with an elevated altitude of 152 meters (NPC, 2006).

\section{Advocacy Pre-Survey Contacts And Ethical Considerations:}

With a letter of introduction from the Department (Appendix), the Secretary, Health Research and Ethical Committee of the health institution was met with a well detailed research proposal, after which an ethical approval was obtained for the research work.

\section{Study Population And Enrolments}

A total number of one hundred and sixty three (163) subjects were enrolled for the study. 113 hepatitis positive subjects ( $\mathrm{HAV}=16 ; \mathrm{HBV}=65 ; \mathrm{HCV}=32$ ) and 50 hepatitis negative subjects that served as the control. The above subjects were people that came for blood donation and were between the ages of 18 and 53 years. Both gender inclusive.

\section{Subject Criteria:}

Written and oral informed consents were obtained from the subjects and other information which was helpful for the study. Also, the subjects were selected after being screened and found to be reactive to hepatitis $\mathrm{A}, \mathrm{B}$, and C Viruses using the chromatographic method. And they were not reactive to other viral infections such as HIV, no history of Tuberculosis; not sicklers, diabetic, etc.

The control subjects were also selected on the grounds that they were screened and found non reactive to any viral infection, Hepatitis A, B, C, HIV, not on any medication or vaccination for the past one to three months.

\section{Exclusion Criteria:}

For the test group, the subjects showing an underlying chronic illness such as diabetes mellitus, cardiovascular, tuberculosis or any other clinical condition other than hepatitis were excluded from the study. Under the control group, subjects reactive to HBV, HCV, HAV, and HIV or any other clinical conditions were excluded.

\section{Sample Collection:} technique.

About $6 \mathrm{ml}$ of venous blood was aseptically collected from each subject with the standard venepuncture

About $4.5 \mathrm{ml}$ was dispensed into a citrated anticoagulant bottle and mixed properly. The remaining was dispensed into an EDTA bottle for platelet count. The samples were centrifuge at 3000rpm for 5 minutes. Coagulation factor analyses were run the same day.

\section{Laboratory Investigations}

All reagents and kits were commercially purchased from a reputable company whose standard operating procedures were strictly followed.

\section{Hepatitis Testing}

\section{A. Hepatitis B Surface Antigen}

The Hepatitis B Virus status of the subjects were ascertained using One step hepatitis B surface antigenic test strip from ABON Biopharm company Plc, China.

Principle: The membrane of the strip is pre-coated with anti-HBsAg antibodies on the test line region. During testing, the serum specimen reacts with the particle coated with anti- HBsAgc antibodies. The mixture migrates upwards on the membrane chromatographically by capillary action to react with anti HBsAg antibodies on the membrane and generate a colored line. The presence of this colored line in the test region indicates a positive result while its absence, indicates a negative result.

\section{Procedure:}

Using a disposable plastic pipette about $50 \mu 1$ of the serum sample was collected and applied on the sample pad, then allowed for 10 minutes for the reaction to occur. After which the result was read.

HCV SCREENING

Procedure: As in HBV Above

\section{C.Hav Screening}

The HAV screening was done with the Onsite HAV IgM Rapid Test-Cassette (Serum/Plasma) by Osumex Company and HAV cassette Rapid test by micopoint Company Ltd, USA. 


\section{Procedure}

Specimen and test cassette were brought to room temperature prior to use. The specimens were mixed well before use. The pouch of the cassette was opened and the test device was placed on a clean, dry, flat surface. About $30-45 \mu 1$ of sample was dispensed into the test well using a disposable pipette. Air bubbles were avoided. Then an equal volume of the buffer was added immediately. A timer was set up. The result was interpreted within 15 minutes.

\section{Hiv Screeing}

\section{Procedure}

$50 \mathrm{ul}$ of plasma was applied to the sample pad. It was allowed for 15 minutes (up to 20 minutes) and result was read.

\section{Coagulation Analysis}

The coagulation profile was done with an automated coagulation analyzer (KL 340).

\section{Activated Partial Thromboplastin Time (APTT) \\ (Modified Kaolin Method) \\ Specimen Collection And Storage}

The blood was drawn and was mixed immediately with anticoagulant (9:1). The mixture was centrifuged for 15 minutes at 2500. The test was done within two hours at room temperature. Plasma samples were stored frozen at $-20^{\circ} \mathrm{C}$ for up to two weeks, for tests not completed the same day (NCCLS, Wayne, 1998).

\section{Procedure}

The sample mixture was placed in plastic or siliconized glass cuvette. $100 \mu$ plasma citrate (supernatant) was added. The $100 \mu \mathrm{l}$ of reagent (prewarmed to $37^{\circ} \mathrm{C}$ ) was added. It was mixed and incubated for $3-5$ minutes at $37^{\circ} \mathrm{C}$. $100 \mu \mathrm{l}$ of prewarmed calcium chloride at $37^{0} \mathrm{C}$, was added. The time for clot formation was recorded by the coaglometer.

\section{Fibrinogen Concentration \\ (Clauss Method, 1957) \\ Procedure}

With Imidazole buffer, the samples and controls were pre-diluted in the ratio $1: 10,(50 \mu 1+450 \mu 1)$. $200 \mu \mathrm{l}$ pre-diluted samples was pippetted in plastic or siliconized glass cuvettes and was incubated for $4-6$ minutes at $37^{0} \mathrm{C} .100 \mu \mathrm{l}$ Bovine thrombin was added. The time for clot formation was obtained in the auto analyzer.

\section{Prothrombin Time Test}

(Quick one stage method, 1935)

Procedure

$100 \mu \mathrm{l}$ of the sample was put in plastic or siliconized glass cuvette. It was incubated for about 2 minutes at $37^{\circ} \mathrm{C} .200 \mu \mathrm{l}$ of reagent (initially prewarmed at $37^{\circ} \mathrm{C}$ was added. It was tested in duplicate.

\section{Thrombin Time}

Procedure:

$100 \mu \mathrm{l}$ of thrombin solution was added to $200 \mu \mathrm{l}$ of control plasma in a glass siliconzed tube at $37^{0} \mathrm{C}$. The time for clot formation was observed. The procedure was repeated in duplicate for patient's and control plasma.

The Results are as tabulated below.

\section{Results}

Table 1: Mean Values of Coagulation factors in Hepatitis A Virus Infection $(n=16)$

\begin{tabular}{|l|l|l|l|lc|}
\hline Groups & $\begin{array}{l}\text { APTT } \\
(\mathrm{Sec})\end{array}$ & $\begin{array}{l}\text { PT } \\
(\mathrm{Sec})\end{array}$ & $\begin{array}{l}\text { TT } \\
(\mathrm{Sec})\end{array}$ & $\begin{array}{l}\text { Fibrinogen } \\
(\mathrm{g} / \mathrm{l})\end{array}$ & $\begin{array}{l}\text { Platelet } \\
10^{9} / 1\end{array}$ \\
\hline I (Control) & $34.1 \pm 3.1$ & $13.4 \pm 1.7$ & $16.7 \pm 1.5$ & $2.5 \pm 0.6$ & $263 \pm 74$ \\
\cline { 1 - 5 } (Test) & $32.8 \pm 2.6^{\mathrm{Ns}}$ & $12.4 \pm 1.5^{\mathrm{Ns}}$ & $16.5 \pm 1.3^{\mathrm{Ns}}$ & $2.9 \pm 0.7^{\mathrm{Ns}}$ & $249 \pm 73^{\mathrm{Ns}}$ \\
\hline
\end{tabular}

$\mathrm{Ns}=$ Statistically not significant 
The Effect of Viral Hepatitis ON APTT, PT, TT, Fibrinogen and Platelet among Blood Donors ....

Table 2: Mean Values of Coagulation Factors in Hepatitis B Virus Infection $(n=65)$

\begin{tabular}{|l|l|l|l|lc|}
\hline Groups & $\begin{array}{l}\text { APTT } \\
(\mathrm{Sec})\end{array}$ & $\begin{array}{l}\text { PT } \\
(\mathrm{Sec})\end{array}$ & $\begin{array}{l}\text { TT } \\
(\mathrm{Sec})\end{array}$ & $\begin{array}{l}\text { Fibrinogen } \\
(\mathrm{g} / \mathrm{l})\end{array}$ & $\begin{array}{l}\text { Platelet } \\
10^{9} / 1\end{array}$ \\
\hline I (Control) & $34.1 \pm 3.1$ & $13.4 \pm 1.7$ & $16.7 \pm 1.5$ & $2.5 \pm 0.6$ & $263 \pm 74$ \\
\hline II (Test) & $42.4 \pm 5.8 *$ & $22.3 \pm 10.7 *$ & $23.9 \pm 4.7 *$ & $1.8 \pm 1.1 *$ & $162 \pm 44 *$ \\
\hline
\end{tabular}

$*=$ statistically significant

Table 3: Mean Values of Coagulation Factors in Hepatitis C Virus Infection $(n=32)$

\begin{tabular}{|c|c|c|c|c|c|}
\hline Groups & $\begin{array}{l}\text { APTT } \\
\text { (Sec) }\end{array}$ & $\begin{array}{l}\mathrm{PT} \\
(\mathrm{Sec})\end{array}$ & $\begin{array}{l}\text { TT } \\
(\mathrm{Sec})\end{array}$ & $\begin{array}{l}\text { Fibrinogen } \\
(\mathrm{g} / \mathrm{l})\end{array}$ & $\begin{array}{l}\text { Platelet } \\
10^{9} / 1\end{array}$ \\
\hline I (Control) & $34.1 \pm 3.1$ & $13.4 \pm 1.7$ & $16.7 \pm 1.5$ & $2.5 \pm 0.6$ & $263 \pm 74$ \\
\hline II (Test) & $45.0 \pm 6.3 *$ & $20.9 \pm 4.9$ * & $24.6 \pm 5.6 *$ & $1.6 \pm 0.6$ * & $170 \pm 61$ * \\
\hline
\end{tabular}

*= statistically significant

Table 4: Correlation Analysis of the Coagulation Parameters:

\begin{tabular}{|c|c|c|c|c|c|c|}
\hline & & aPTT & PT & TT & Fibrinogen & Platelet \\
\hline \multirow[t]{3}{*}{ Aptt } & Pearson Correlation & 1 & $.293 * *$ & $.445 * *$ & $-.340 * *$ & $-.443 * *$ \\
\hline & Sig (2-tailed) & - & .000 & .000 & .000 & .000 \\
\hline & $\mathrm{N}$ & 163 & 163 & 163 & 163 & 163 \\
\hline \multirow[t]{3}{*}{ PT } & Pearson Correlation & $.293 * *$ & 1 & $.339 * *$ & $-.175 *$ & $-.365 * *$ \\
\hline & Sig (2-tailed) & .000 & - & .000 & .025 & .000 \\
\hline & $\mathrm{N}$ & 163 & 163 & 163 & 163 & 163 \\
\hline \multirow[t]{3}{*}{$\mathrm{TT}$} & Pearson Correlation & $.445 * *$ & $.339 * *$ & 1 & $-.378 * *$ & $-.356 * *$ \\
\hline & Sig (2-tailed) & .000 & .000 & - & .000 & .000 \\
\hline & $\mathrm{N}$ & 163 & 163 & 63 & 163 & 163 \\
\hline \multirow[t]{3}{*}{ Fibrinogen } & Pearson Correlation & $-.340 * *$ & $-.175 * *$ & $-.378 * *$ & 1 & $.293 * *$ \\
\hline & Sig (2-tailed) & .000 & .025 & .000 & - & .000 \\
\hline & $\mathrm{N}$ & 163 & 163 & 163 & 163 & 163 \\
\hline \multirow[t]{3}{*}{ Platelet } & : Pearson Correlation & $-.443 * *$ & $-.365 * *$ & $-.356 * *$ & $.293 * *$ & 1 \\
\hline & Sig (2-tailed) & .000 & .000 & .000 & .000 & - \\
\hline & $\mathrm{N}$ & 163 & 163 & 163 & 163 & 163 \\
\hline
\end{tabular}

As indicated in table 1 above, In HAV-infection, it was observed that the mean values of the coagulation factors aPTT, PT, TT, and platelet $\left(32.8 \pm 2.6 \mathrm{secs} ; 12.4 \pm 1.5 \mathrm{sec} ; 16.5 \pm 1.3\right.$ (secs); $2.9 \pm 0.7^{\mathrm{g}} / \mathrm{L}$ and $249 \pm 73 \pm 73\left(10^{9} / \mathrm{L}\right)$ respectively showed no Significant changes when compared with the controls $(34.1 \pm 3.1$ (sec); $13.4 \pm 1.7$ (secs); $16.7 \pm 1.5(\mathrm{sec}) ; 2.5 \pm 0.6 \mathrm{~g} / \mathrm{L}$ and $263 \pm 74\left(10^{9} / \mathrm{L}\right)$ at $\mathrm{P}<0.05$.

As indicated in table 2, following HBV infection, all the coagulation factors aPTT, PT, TT, fibrinogen and platelets $\left(42.4 \pm 5.8(\mathrm{sec}) ; 22.3 \pm 10.7(\mathrm{secs}) ; 23.9 \pm 4.7(\mathrm{secs}) ; 1.8 \pm 1.1(\mathrm{~g} / \mathrm{L}) ;\right.$ and $162 \pm 144\left(10^{9} / \mathrm{L}\right)$, showed a significant change when compared with the control respectively (34.1 \pm 3.1 (secs), $13.4 \pm 1.7$ (secs); $16.7 \pm 1.5(\mathrm{secs}) ; 2.5 \pm 0.6(\mathrm{~g} / \mathrm{L})$; and $263 \pm 74\left(10^{9} / \mathrm{L}\right)$ at $\mathrm{P}<0.05$.

As indicated in table 3 , there was also a significant change in all the coagulation parameters in HCV infection $\left(45.0 \pm 6.3(\mathrm{secs}) ; 20.9 \pm 4.9(\mathrm{secs}) ; \quad 24.6 \pm 5.6(\mathrm{secs}) ; \quad 1.6 \pm 0.6(\mathrm{~g} / \mathrm{L})\right.$ and $170 \pm 61\left(10^{9} / \mathrm{L}\right)$ when compared with the control $\left(34.1 \pm 3.1(\mathrm{secs}) ; 13.4 \pm 1.7(\mathrm{secs}) ; 16.7 \pm 1.5(\mathrm{secs}) ; 2.5 \pm 0.6(\mathrm{~g} / \mathrm{L}) ; 263 \pm 74\left(10^{9} / \mathrm{L}\right)\right.$ respectively at $\mathrm{P}<0.05$ when compared with the control $(34.1 \pm 33.1$ (secs); $13.4 \pm 1.7$ (secs); $16.7 \pm 1.5$ (secs); 2.5 $\pm 0.60 .6(\mathrm{~g} / \mathrm{L})$; and $263 \pm 74\left(10^{9} / \mathrm{L}\right)$ respectively at $\mathrm{P}<0.05$.

In the correlation analysis, aPTT showed a positive relationship with PT and TT and a negative relationship with fibrinogen and platelet.

PT showed a strong positive correlation with TT while having negative relationships with fibrinogen and platelet. TT was found to have a strong negative relationship with fibrinogen and platelet. The same relationship was observed also in the coagulation factors when correlated vice versa.

\section{Discussion}

The liver plays a major role in haemostasis as most of the coagulation factors, anticoagulant proteins and components of the fibrinolytic system are synthesized by the hepatic parenchymal cells. But when the liver is diseased, these functions are impaired.

The study on the effects of hepatitis A, B and C on some coagulation factors was designed to assess the changes associated with some coagulation factors following viral hepatitis (A, B and C).

In this study, it was observed that in hepatitis A virus infection, there was no statistically significant changes in the mean values of all the coagulation factors. The reason for the observation could be based on the fact that hepatitis A virus being a self-limiting infection, does not progress to cirrhosis (Zinego et al., 2007) 
hence does not cause chronic hepatitis. The infection with HAV infection was not as much prevalent as other viral infection ( $\mathrm{HBV}$ and $\mathrm{HCV}$ ) as it is transmitted through fecal-oral route and there is increased awareness and people have come to the knowledge of the need for good sanitary, hygienic and healthy living. The nonsignificant increase in fibrinogen observed in HAV infection could be as a result of its involvement in acute phase reaction and/or the presence of abnormal non-functional fibrinogen (dysfibrinogenaemia) related to defective polymerization.

In Hepatitis B virus infection (HBV), there was an observed statistical change in all the coagulation factors analyzed. According to Yang-Mei et al, (2008), infection of the liver by virus causes virus-induced tumor necrosis factor production which mediates a significant liver pathology. These changes can therefore be explained based on the state of the diseased liver which is saddled with the responsibility of clotting factors synthesis (William, 2003).

The loss of hepatic function following HBV infection could arise also from hepatic inflammation caused by HBX (hepatitis B virus x protein) which is pro-inflammatory cytokines including inter-leukin - 18 . (IL-18). The IL-18 in turn increases the expression of Fasl (Fas-Ligand) which leads to increased susceptibility to fas-mediated cell apoptosis (Poli, 2000).

Again the deficiency of vitamin K-dependant factors due to liver diseases reduces hepatic synthesis and reduced absorption of bile salts required for absorption of vitamin K-dependant factors especially the prothrombin and fibrinogen.

In hepatitis $\mathrm{C}$ virus infection, a prolonged aPTT, PT and TT was observed with decrease in fibrinogen and platelet levels. HCV infected people have been suggested by researchers that they fail to clear the virus during the acute phase of the disease and as result become chronic carriers. This is because of the envelop protein $\mathrm{E} 1$ and $\mathrm{E} 2$ which are produced against $\mathrm{HCV}$ infection whose hypervariable regions have been known to prevent the antibodies from clearing the disease. It is therefore the chronic exposure to activation of the humoral immune system to $\mathrm{HCV}$ and the failure to clear the infection that results to repeated exposure to self reactive antibody with consequent organ damage (Sy and Jamah, 2006). Also, HCV induces a strong T-Cell reaction, generating responses from Th1 and Th2 cells and the high titre of TL1 Cytokines which include IL-2, TNFalpha and IFN-gamma in particular correlates with fibrosis and inflammation (Sy and Jamal, 2006) that cause hepatic dysfunction.

The adverse effect which HBV and HCV exert in the liver such as bleeding tendency, anaemia, thrombosis, decreased granulocytes and even multiple organ failure (Yan-Mei et al, 2008) stems from their ability to persist in the host for years and principally contribute to the establishment of chronic hepatitis (Nakamoto, 2003).

The liver damage caused by HCV infection with resultant effect in the coagulation factors as observed in this study could also be explained from the increased oxidative stress arising from increased production of inflammatory cytokines. These reactive oxygen species (ROS) in turn induce the proliferation of hepatic stellate cells TGF-B Collagen Synthesis (Poli, 2000), which plays an important role in the development of liver fibrosis.

The increased levels of ROS following viral hepatitis have been suggested to promote the development of hepatocellular carcinoma by inducing DNA damage and mutation of cellular genes (Machida et al., 2004) with resultant loss of hepatic functions including the synthesis and clearing of the coagulation factors.

The mechanism by which HCV causes oxidative stress is through its protein NS5A which increases mitochondrial ROS generation by perturbing the cytosolic $\mathrm{Ca}^{2+}$ (Calcium) concentration indirectly through endoplasm reticulum (ER) stress. The NS3 protein of HCV induces oxidative stress also by activating nicotinamide adenine dinucleotide phosphate oxidase of kupffer cells and polymorphonuclear cells in the liver, hence, triggering cell apoptosis (Thoren et al, 2004).

It is this progressive loss of hepatic parenchymal cells occasioned by these virus infections that result in clotting factor deficiencies and elevations as the case may be.

The marked thrombocytopenia in both $\mathrm{HBV}$ and $\mathrm{HCV}$ infections could be explained from the impaired hepatic synthesis of thrombopoetin which is the principal physiological regulator of platelet production and synthesized constitutively in the liver (Kuter and Begley, 2002). The thrombocytopenia observed in this study is in agreement with the finding of Young Xiang et al, (2002), that platelet count correlates inversely with the number of phagocytically active splenic macrophages supporting their role in the pathogenesis of thrombocytopenia. the thrombocytopenia could also arise from increased sequestration of platelet in an enlarged spleen, impaired platelet production, an immune and non-immune mediated platelet destruction as well as the production of nitric oxide which is a powerful vasodilator and inhibitor of platelet adhesion and aggregation (Jody and Kujovich, 2005). The observation is also in line with the study carried out by Hyer et al (2001) which maintained that viral infection is associated with prolongation of PT, APTT, TT, dysfibrinogenemia and thrombocytopenia. This is as a result of the loss of the integrity of both the entrinsic pathway of coagulation and factors of the common pathway. 
In the current study, the prolongation of clotting time is in line with the finding of the Hyer et al, (2001) which maintained that the prolongation in the clotting time correlates with the degree of deficiency or inhibition of extrinsic or common pathway, hence the degree of liver damage.

The explanation of this prolongation is because of the abnormal fibrin polymerization caused by an increased salic acid content of $\beta$ and $\square$-chains of fibrinogen due to excessive production of salic acid tranferase. The dysfibribogenaemia and thrombocytopenia observed in this study explained better the bleeding tendency seen in these patients .

In the correlation analysis, the negative and positive relationships existing among coagulation parameters studied, explain their complex nature in the maintenance of haemostasis as a derangement in one factor can affect others adversely. At a reduced fibrinogen level, the formation of fibrin by thrombin is impaired. This results in a prolongation of the activated partial thromboplastin time (APTT).

\section{Conclusion:}

From the findings in this study, it can be deduced that there are alterations in the coagulation factors in hepatitis. The degree of alterations indicates the severity of the liver disease.

\section{References}

[1]. Blanchard, R. A., Furie, B. C., and Jorgensen, M., (1981). Acquired Vitamin K-dependent Carboxylation deficiency in Liver disease. New England Journal of Medicine: 305: 242-248.

[2]. Dacie and Lewis (2001)"Haemostasis" In test book of practical Haemetology. $9^{\text {th }}$ Edition. Ed: Lewis, S.M., Bain, B.J., and Bates, I.) Churchill Livingstone London pp 339-342.

[3]. Emechebe, G.O., Emodi, I.J., Ikefuna, A.N., Ilechukwu, G.C., Igwe, W.C., and Ejiofor, O.S., (2009). Hepatitis infection in Nigeriaa review. Nigeria journal of medicine $\mathbf{5 0}(1): 18-22$.

[4]. Francesca, R. P., valerio, De.S., and Antorio, G., (2009) Viral Grrhosis: an overview of haemostatic and Clinical Consequences. Meditterean Journal of Haematology and infections Diseases 1(3):

[5]. Hyers, T.M., Agneli, G., and Hill, R.D., (2001). Antithrombotic theraphy for venous thromboembolic disease. Chest: 119: 176-193.

[6]. Jody, L. and Ryovich, M.D., (2005). Hemo Static Defects in End stage liver Disease. Critical care and clinical 21:563-587.

[7]. Kuter, D.J., and Begley, C.G., (2002). Recombinant human Thrombopoietin: basic biology and evaluationof clinical studies. Blood 100: $3457-3469$.

[8]. Poli, G., (2000). Pathogenesis of liver fibrosis: role qxidation stress molecular Aspect of medicine 21: 49-98.

[9]. Quick, A., J., Stanley-Brown, M., and Bancroft, F.W., (1935). A study of the coagulation defect in hemophilis and in Jaundice. America Journal of medical science 190:501.

[10]. Ryder, S., and Beckingham, I., (2001). “Acute Hepatitis. BMJ 332 (7279): 151 - 153.

[11]. Thoren, F., Romero, A., Lindh, M., Dahlgren, C., and Hellstrand, K. (2004). A hepatitis C virus-encoded, nonstructural protein (NS3) triggers dysfunction andapoptosis in lymphocytes: role of NADPH oxidase- derived oxygen radicals. J Leukoc Biol 76. 1180-1180.

[12]. William, F.G., (2003). Haemostais" In textbook of review of Medical Physiology.21 $1^{\text {st }}$ Edition.McGrawhill. p. $543-546$.

[13]. Yan - Mei, L., Hong - Zhi, Y., Wei - Bing, G., Qian - Shan, K., Min, D., He - Ping, X., and Shi - Jun, Z., (2008). The Therapeutic Effect of Traditional Chinese Medicine on Coagulation Disorder and accompanying Intractable Jaundice in HBV -Related Liver Cirhosis Patients. World Journal of Gastroenterology 14 (39): 6060 - 6064.

[14]. Yong Xiang, W., Zongfang, L., and Guowei, L., (2002). Effects of Splenonegaly and Splenic macrophage activity in hypersplenism due to Grrhosis. American Journal of Medicine 113:428-431.

[15]. Nakamoto, Y., (2003) Mechanism of Viral Hepatitis Induced Liver Injury. Current Molecular Medicine 3 (6): 537 - 544.

[16]. Sy, T., and Janal, M. (2006) Epidemiology of Hepatitis C virus (HCV) infection. International Journal of Medical Science 3: $41-46$

[17]. Zignego, A.L., Ferri, C., and Pileri, S.A., (2007). "Extragepatic manifestation of Hepatitis C virus infection; a general overview and guidelines for a clinical approach". Digestive and Liver Disease 39 (1); 2-17.

[18]. Wayne, P.A. (1998) "NCCLS: Collection, Transport and Processing of Blood Specimens for Coagulation Testing and General Performance of 